\title{
Growth of Very Low Birth Weight Infants on Varying Amounts of Human Milk Protein
}

\author{
S. K. T. POlBERGER, I. A. AXELSSON, AND N. C. E. RÄIḦ̈ \\ Department of Pediatrics, University of Lund, Malmö General Hospital, S-21401 Malmö, Sweden
}

\begin{abstract}
In a double-blind, randomized study, 28 healthy, growing very low birth wt, appropriate-for-gestational-age infants were fed human milk, preferably mother's own, fortified daily with human milk protein and/or human milk fat. The infants entered the study when they were stable on complete enteral intakes of $170 \mathrm{~mL} / \mathrm{kg} / \mathrm{d}$ (mean age $=19 \mathrm{~d}$ ). The study lasted for a mean of $4 \mathrm{wk}$. Samples from all the milks were collected daily, and intakes of protein, fat, carbohydrates, energy, and electrolytes were calculated weekly during the whole study period. Protein intakes ranged from 1.7 to $3.9 \mathrm{~g} / \mathrm{kg} / \mathrm{d}$, and energy intakes from 100 to $150 \mathrm{kcal} / \mathrm{kg} / \mathrm{d}$. Wt and length gain in the nonprotein-enriched groups were $15.6 \pm 2.7 \mathrm{~g} / \mathrm{kg} / \mathrm{d}$ (mean $\pm \mathrm{SD}$ ) and $0.88 \pm 0.17 \mathrm{~cm} / \mathrm{wk}$; the corresponding figures for the protein-enriched groups were $20.2 \pm 2.1 \mathrm{~g} /$ $\mathrm{kg} / \mathrm{d}$ and $1.24 \pm 0.14 \mathrm{~cm} / \mathrm{wk}$. There was a strong correlation between protein intake and growth in wt and length up to an intake of about $3 \mathrm{~g} / \mathrm{kg} / \mathrm{d}$; more protein did not result in increased growth. The same was true for energy intake, with a maximal growth rate at an intake of about $120 \mathrm{kcal} /$ $\mathrm{kg} / \mathrm{d}$. A protein intake of more than $3 \mathrm{~g} / \mathrm{kg} / \mathrm{d}$ resulted in a growth rate equal to or higher than the estimated intrauterine growth rate. Some infants fed mature banked human milk alone had a poor growth. Sodium intake was low, ranging from 1.5 to $2.6 \mathrm{mmol} / \mathrm{kg} / \mathrm{d}$. No correlation was found between sodium intake and growth rates. (Pediatr Res 25:414-419, 1989)
\end{abstract}

\section{Abbreviations}

VLBW, very low birth wt $(<1500 \mathrm{~g})$

AGA, appropriate-for-gestational-age

NMR, nuclear magnetic resonance

HM, human milk

HMF, human milk + human milk fat

HMP, human milk + human milk protein

HMFP, human milk + human milk fat + human milk protein

The optimal protein intake of the VLBW infant is still a matter of controversy, and widely varying recommendations are given $(1,2)$. Banked human milk was used for many years as the main source of protein for feeding these infants, but growth data in the literature are contradictory (3-7). This may be attributable to different gestational ages and wt of the infants studied, different methods of administering the milk (continuous or intermittent nasogastric or nasojejunal tube feeding), treatment of the

Received June 28, 1988; accepted November 17, 1988.

Correspondence to Dr. Staffan Polberger, Department of Pediatrics, Malmö Gencral Hospital. S-21401 Malmö, Sweden.

Supported in part by the Swedish Medical Research Council, Grant No. B8519X-06259, and Stiftelsen Samariten. milk before administration (pasteurization, boiling, etc.), and the way of collecting the milk (expression by pump or use of drip milk). Milk from mothers delivering preterm (preterm-milk) has, at least during the early wk of lactation, a higher protein content which may better correspond to the requirements of the VLBW infant $(8,9)$. Recent studies also indicate that the growth rate in VLBW infants fed preterm-milk is higher compared to bank milk $(10,11)$ and equal to formula feeding $(12,13)$. Cow's milk formulas for VLBW infants with a higher energy and protein content have been widely used during the last decade, permitting growth equal to the estimated intrauterine rate $(14,15)$. However, the protein quality and amino acid content in formulas are not the same as human milk (3). During the last years, a few studies have been published on feeding the VLBW infant with human milk enriched with human milk protein resulting in an increased growth rate compared to that found in infants fed unfortified human milk $(13,16,17)$. To obtain a model for optimal protein and energy nutrition in VLBW infants, we designed a study in which human milk, preferably the mother's own, or when not available, mature bank milk was fortified with ultrafiltered human milk protein and/or human milk fat. Our goal was to achieve a growth rate equal to the intrauterine rate for the period studied and to obtain indices of protein metabolism comparable to those found in growing breast-fed term infants.

\section{MATERIALS AND METHODS}

Patient selection and study design. The study was performed at the two neonatal units of the University of Lund located in Malmö and Lund. All efforts were made to minimize possible differences in clinical routines between the two units, and one of the investigators (SP) has worked at both units during the study period to equalize nursery and medical routines for VLBW infants.

The criteria for acceptance of an infant to the study were: 1 ) birth wt $<1500 \mathrm{~g}, 2) \mathrm{AGA}, 3)$ tolerance of complete enteral feeding $(170 \mathrm{ml} / \mathrm{kg} / \mathrm{d}), 4)$ no obvious disease or major malformations, 5) no oxygen therapy, and 6) informed parental consent and acceptance of a blind trial.

The study was carried out as a "double-blind," randomized (closed envelopes) controlled trial.

The trial was continued until a wt of about $2.2 \mathrm{~kg}$ or to the time when breast-feeding was initiated.

Feeding regimens and nursery routines. The infants were randomly assigned to one of the following four feeding regimens: $l$ ) $\mathrm{HM}$ (control group), 2) HM + HMF (+1 g/dL), 3) HM + HMP $(+1 \mathrm{~g} / \mathrm{dL})$, and 4) HM + HMFP (HMF, $1 \mathrm{~g} / \mathrm{dL}+\mathrm{HMP}, 1 \mathrm{~g} /$ dL). The intake was maintained at $170 \mathrm{ml} / \mathrm{kg} / \mathrm{d}$ during the whole study period. Intakes were adjusted daily on the basis of body wt.

When possible, the mother's own milk was used for feeding. When the mother's milk was not available, mature human milk from the milk bank was used. All milks were expressed with an electric breast pump. The milk was either used fresh or stored at 
$-20^{\circ} \mathrm{C}$ and thawed before use. No milks were pasteurized according to existing routines at the time of the study. The bank milk was routinely controlled bacteriologically and found acceptable.

All infants were enterally supplemented with vitamin $\mathrm{E}$ from birth, and starting on the 3rd d with folic acid, a multivitamin preparation (Protovit), and an additional 700 IU of vitamin D (calciferol), giving a total daily intake of vitamin D of $1200 \mathrm{IU}$. On d 5 , an extra intake of 30 and $20 \mathrm{mg} / \mathrm{kg} / \mathrm{d}$ of calcium and phosphorus was administered as calcium lactate and sodium phosphate, respectively. From 4 wk of age, elemental iron (2 $\mathrm{mg} / \mathrm{kg} / \mathrm{d}$ ) was administered. All infants were started on enteral feeding on their 1 st $d$ of life.

The infants were nursed in closed incubators at a thermoneutral temperature until a wt of about $2 \mathrm{~kg}$, when they were placed into open cribs. Until a wt of $1500 \mathrm{~g}$ was reached, all infants were kept under an inner plastic shelter as well. The feeds were delivered as a bolus by a nasogastric tube every $3 \mathrm{rd} \mathrm{h}$. After each meal, the feeding tube was rinsed with $1 / 2 \mathrm{~mL}$ of sterile water.

Characteristics of study population. Of 34 infants who were randomized and enrolled, 28 assigned to the four feeding groups completed the study. The six infants not fulfilling the study were distributed among the four feeding groups, and the reasons for exclusion were: apnea $(n=2)$, intolerance to accepting the fixed vol $(n=3)$, and need for intravenous therapy $(n=1)$.

Birth and study data for the infants in the different feeding groups are presented at Table 1. There was a difference in sex distribution between the groups, but later analyses confirmed that this difference has no implications on the results. Birth wt was regained after a mean time of $13 \mathrm{~d}$; only two infants had not reached their birth wt when entering the study (both did so after another $2 \mathrm{~d}$ ). The infants were studied for a mean time of $28 \mathrm{~d}$ (range 19-37 d), except one, who stayed in the study for $48 \mathrm{~d}$.

No significant differences were found between the feeding groups. Gestational age had been determined by ultrasound at wk 17 in 20 of the 28 infants. Assessment of gestational age of the remaining eight infants was based on the last menstrual date and clinical assessment. Three infants had Apgar scores less than 7 at $5 \mathrm{~min}$. Only two of the infants had been on a ventilator (because of respiratory distress syndrome), one of 16 examined infants had a subependymal hemorrhage (grade 1) on routine ultrasound scanning; the others had normal scans. Two infants had developed patent ductus arteriosus which closed (without an operation) before the start of the study. All 28 infants had received intravenous infusions of glucose and electrolytes for a median time of $6 \mathrm{~d}$; seven infants had been on partial parenteral nutrition before entering the study. No infant developed signs of necrotizing enterocolitis, hydrocephalus, or bronchopulmonary dysplasia.

Table 1. Characteristics of study population*

\begin{tabular}{|c|c|c|c|c|}
\hline & $\begin{array}{c}\mathrm{HM} \\
(n=7)\end{array}$ & $\begin{array}{l}\mathrm{HMF} \\
(n=7)\end{array}$ & $\begin{array}{l}\text { HMP } \\
(n=7)\end{array}$ & $\begin{array}{l}\text { HMFP } \\
(n=7)\end{array}$ \\
\hline Sex (male/female) & $3 / 4$ & $3 / 4$ & $6 / 1$ & $4 / 3$ \\
\hline Birth wt $(\mathrm{g})$ & $1250 \pm 160$ & $1235 \pm 185$ & $1165 \pm 115$ & $1220 \pm 175$ \\
\hline $\begin{array}{l}\text { Birth gestational } \\
\text { age (completed } \\
\text { wk) }\end{array}$ & $28.7 \pm 0.8$ & $28.3 \pm 1.1$ & $27.6 \pm 1.4$ & $29.6 \pm 1.6$ \\
\hline $\begin{array}{l}\text { Age at study start } \\
\text { (d) }\end{array}$ & $21.7 \pm 8.5$ & $20.6 \pm 9.7$ & $21.6 \pm 4.7$ & $14.4 \pm 5.1$ \\
\hline $\begin{array}{l}\text { Wt at study start } \\
\text { (g) }\end{array}$ & $1400 \pm 210$ & $1340 \pm 150$ & $1320 \pm 150$ & $1300 \pm 200$ \\
\hline Study period $(\mathrm{d})$ & $26.4 \pm 6.1$ & $29.4 \pm 5.4$ & $28.9 \pm 9.0$ & $27.7 \pm 6.2$ \\
\hline Wt at study end $(\mathrm{g})$ & $2070 \pm 350$ & $2110 \pm 200$ & $2320 \pm 180$ & $2250 \pm 160$ \\
\hline $\begin{array}{l}\text { Gestational age at } \\
\text { study start (d) }\end{array}$ & $225 \pm 7$ & $221 \pm 7$ & $226 \pm 8$ & $225 \pm 8$ \\
\hline $\begin{array}{l}\text { Gestational age at } \\
\text { study end (d) }\end{array}$ & $252 \pm 4$ & $251 \pm 7$ & $255 \pm 5$ & $253 \pm 7$ \\
\hline
\end{tabular}

$*$ Values represent mean $\pm \mathrm{SD}$.
All infants were discharged from the hospital in good condition.

Milk preparation. Human milk fat was separated from pasteurized mature HM in a semiindustrial scale at the Nordreco Company, Bjuv, Sweden. The defatted milk was ultrafiltered, leaving a protein concentrate which was freeze-dried and packed in sterile foil-laminated pouches and stored at $-20^{\circ} \mathrm{C}(18)$. The protein powder consisted of about $70 \%$ protein.

According to which feeding group the infant belonged to, the calculated amount of milk required for the next $24 \mathrm{~h}$ was supplemented with fat or protein or both at the hospital milk banks. After shaking, an aliquot was removed daily and frozen individually for later weekly analyses of the nutritional composition.

Milk analyses. The daily samples of milk were thawed, pooled to representative weekly samples, and analyzed for the content of energy, protein (nitrogen), fat, lactose, sodium, potassium, calcium, and osmolality.

All analyses were made in duplicate. Dry matter was determined from $2 \mathrm{~mL}$ of milk after drying at $110^{\circ} \mathrm{C}$ to constant weight. Ash content was assayed after combustion at $600^{\circ} \mathrm{C}$.

Total nitrogen was determined on 3-mL samples of human milk by the Kjeldahl procedure using Tecator Kjeltec equipment. Protein content was calculated from $\mathrm{g} \mathrm{N} \times 6.25$.

Carbohydrates consisting mainly of lactose and oligosaccharides, were analyzed by the anthrone reaction (19), with a boiling time of $10 \mathrm{~min}$. Lactose was used as a standard.

The total fat content was analyzed by NMR using a Newport analyzer MK II (Falling Number AB, Stockholm), provided with a sample temperature controller (type WR II). The Newport analyzer was operated at sample temperature $70^{\circ} \mathrm{C}$, gate width 1.5 , radio frequency level $100 \mu \mathrm{A}$, amplifier gain 700 , and integration time $32 \mathrm{~s}$.

A 1-g sample of lyophilized and homogenized milk powder was weighed and put into an oven $\left(150^{\circ} \mathrm{C}\right)$ overnight. After cooling in a exsiccator, the sample was reweighed and put into a tube $(6.5 \mathrm{~mL})$, which was placed on a heating chamber at $70^{\circ} \mathrm{C}$ until assayed. Each sample was analyzed in duplicate, and the fat content was calculated from a mean of five NMR signals with ister as a reference. The coefficient of variation was below $2 \%$. Some samples were also analyzed using an extraction method. As we found good agreement between the results from both methods, we decided to continue with the simpler NMR technique.

Energy was generally calculated using the factors: $4.40 \mathrm{kcal} / \mathrm{g}$ protein, $3.95 \mathrm{kcal} / \mathrm{g}$ carbohydrate, and $9.25 \mathrm{kcal} / \mathrm{g}$ fat $(20)$.

The energy value was also analyzed by complete combustion using a bomb calorimeter (Gallenkamp Ballistic Calorimeter). A $5-\mathrm{ml}$ sample of the milk was lyophilized and further dried in an oven to constant wt. The energy value obtained by bomb calorimetry was corrected for the incomplete combustion of protein in the human body $(5.23 \mathrm{~kJ} / \mathrm{g})$. Although slight differences were observed in some of the samples, the mean calculated and analyzed values did not significantly differ (Student's $t$ test).

The calcium, sodium, potassium, and osmolality content of the milks were determined using routine clinical chemical methods.

Growth variables. The infants were weighed to the nearest 10 g each morning by nurses, and crown-heel length and occipitofrontal circumference were measured weekly by the investigators (SP or IA).

Statistical methods. Statistical evaluations were performed at the Department of Statistics, University of Lund, by Professor Jan Lanke and Robyn Attewell, M.Sc. For the analyses, the SPSS program was used in a VAX computer at the Lund University Computing Center.

For each infant, three summary growth measures were calculated by regressing the logarithm of wt, length, and head circumference separately on time. All subsequent statistical analyses were performed using the slopes of the regressions as measures of growth. The slopes were translated into the more natural units 


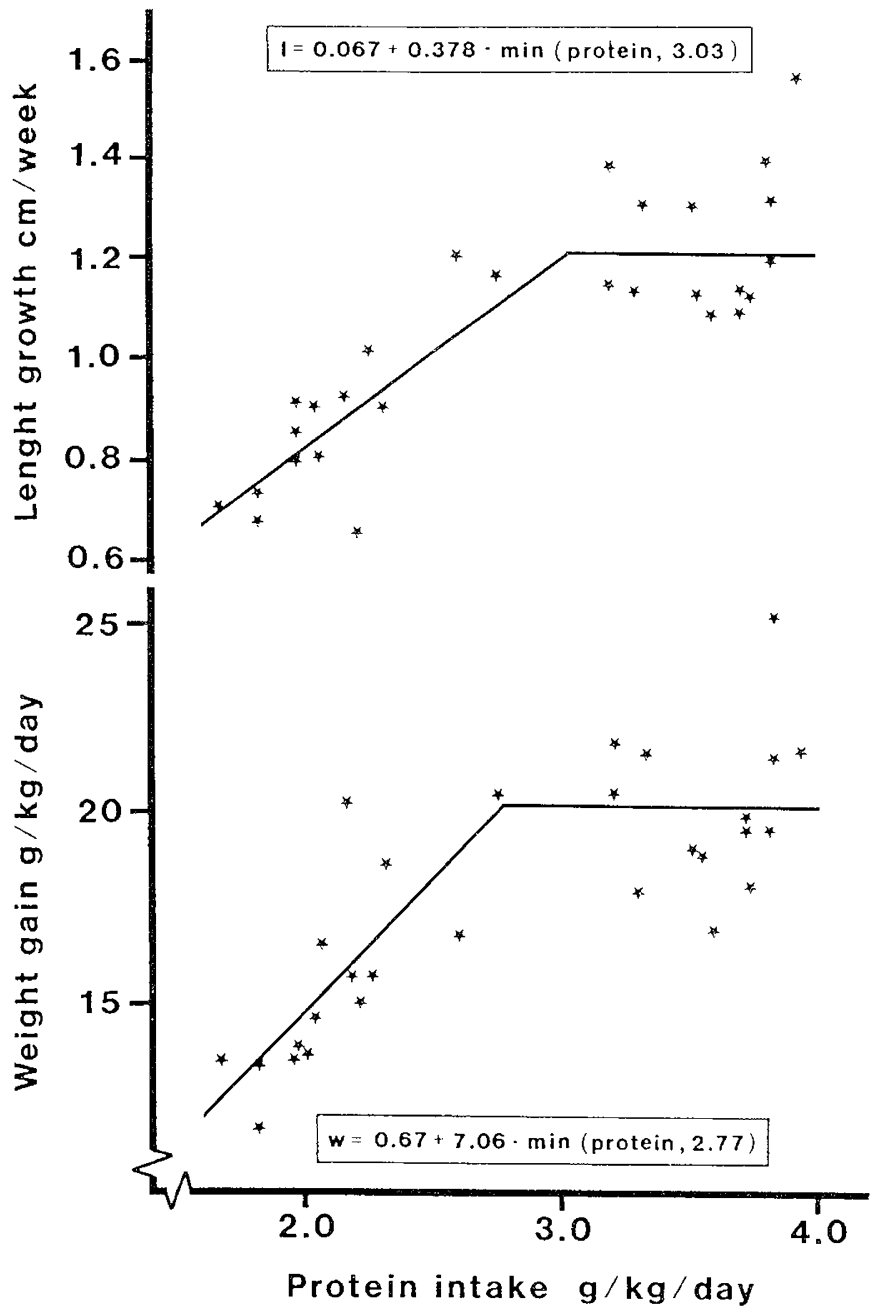

Fig. 1. Wt and length growth vs, protein intake.

$\mathrm{g} / \mathrm{kg} / \mathrm{d}$ and $\mathrm{cm} / \mathrm{wk}$ for wt and length, respectively, as shown in Figures 1 and 2. For wt, the slope was exponentiated and then multiplied by 1000 . For length, after exponentiating the slope and multiplicating by 7 , we multiplied the length by 41.88 (the mean length in $\mathrm{cm}$ of the 28 infants during the study period).

The protein and energy content of milk was characterized for each infant over the study time by calculating the average of the analysis data, weighted according to the lengths of the period of time that each pooled sample refers to. We then tried to explain growth by these milk parameters by studying wt, length, and head circumference growth as functions of protein and energy intake. The correlations $(r)$ and adjusted percentages of variance explained were then calculated:

$$
\mathrm{R}^{2} \text { adj }=1-(n-1 / n-\mathrm{P}) \times\left(1-\mathrm{r}^{2}\right)
$$

where $n=$ number of infants and $\mathrm{p}=$ number of parameters. Ordinary first $(p=2)$ and second order $(p=3)$ regressions, as well as linear $(p=2)$ regression on logarithms were performed. Two other models were then tried as well: linear regression with a cut-point to the right of which the regression curve is horizontal (horizontal regression, $\mathrm{p}=3$ ), and a cut-point where the slope may change (oblique regression, $p=4$ ). Each of these two models was fitted with a trial-and-error technique. The horizontal model was found by using ordinary linear regression of $y$ on $\min (x, a)$ where $a$ is a tentative cut-point; then $\mathrm{R}^{2}$ adj is maximized numerically by trying different values of $a$ by moving the cut-point progressively along the milk axis and choosing the point which gives the best fit to the data. The oblique model was fitted by means of a multiple linear regression of $y$ on $x$ and $(x-a)_{+}$, where the latter quantity denotes the positive part of $x-a$; then $a$ is chosen so as to maximize $\mathrm{R}^{2}$ adj. It should be observed that, in both cases, the values $\mathrm{R}_{\text {adj }}^{2}$ furnished by the computer program are inappropriate as the model contains one parameter more than is obvious to the program. Thus, one has to make the adjustments oneself. When comparing the influence on growth of two or more variables (as referred to in "Results), multiple linear regression was performed.

The study was approved by the Ethical Committee at the University of Lund.

\section{RESULTS}

Nutrient intakes. The mean intake of each major nutrient in the four groups of infants is summarized in Table 2 . The amount of mother's own milk given during the trial showed a great variation. Five mothers (18\%) delivered all milk to their infants; $10(36 \%)$ delivered practically none. The remaining 13 infants received a mixture of mother's own and mature bank milk. No differences were observed in the gastrointestinal tract tolerance to the milk in either group.

Protein. The protein intake varied from 1.7 to $3.9 \mathrm{~g} / \mathrm{kg} / \mathrm{d}$. One mother expressing all milk needed for her infant delivered a protein-rich milk (mean $1.6 \mathrm{~g} / \mathrm{dL}$ ); some infants in the control group $(n=3)$ received a low-protein diet $(<1.1 \mathrm{~g} / \mathrm{dL})$. Protein contributed to $7-14 \%$ of the total caloric intake.

Fat and energy. The fat intake showed a remarkable variation (range 2.5 to $5.8 \mathrm{~g} / \mathrm{kg} / \mathrm{d}$ ). Some mothers delivered a low-fat milk; others continued to produce a high-energetic milk throughout the study period. Energy intake ranged from 100 to $150 \mathrm{kcal} /$ $\mathrm{kg} / \mathrm{d}$.

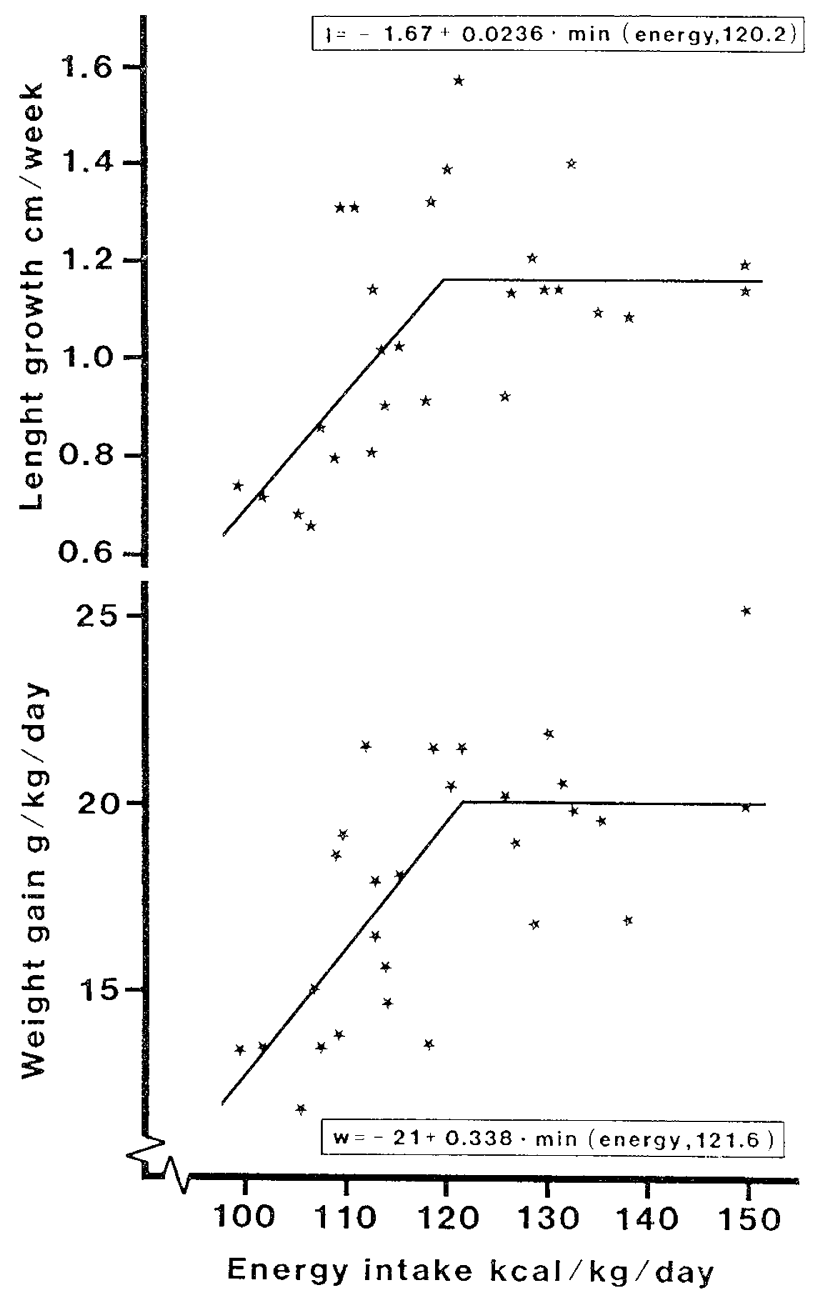

Fig. 2. Wt and length growth $v s$. energy intake. 
Sodium. The sodium intake was generally low, varying between 1.5 and $2.6 \mathrm{mmol} / \mathrm{kg} / \mathrm{d}$. The enrichment of the milk did not increase the sodium content. Supplementation with sodium phosphate increased the daily intake by $0.65 \mathrm{mmol} / \mathrm{kg} / \mathrm{d}$.

Calcium and phosphorus. The calcium intake was increased by about $35 \%$ when milk was enriched with protein, probably by protein binding of calcium during ultrafiltration (14). Supplementation with calcium lactate increased the intake by 0.75 $\mathrm{mmol} / \mathrm{kg} / \mathrm{d}$. Preliminary data also suggest increasing the phosphorus content by about $30 \%$ when the milk is being protein enriched.

Osmolality. The osmolality was $268 \pm 18 \mathrm{mosmol} / \mathrm{kg}$ (mean $\pm \mathrm{SD}$ ) in the nonprotein-enriched groups and $299 \pm 25 \mathrm{mosmol} /$ $\mathrm{kg}$ in the protein-enriched groups. Fat fortification had no influence on osmolality.

Growth versus protein intake. Wt gain and length growth showed a clear increase with increasing protein intake (Fig. 1). Head circumference showed so little relation to protein intake that it was not included in further statistical evaluation (Table 3 ). Wt and length did not increase linearly with protein; the rate of increase seemed to be faster at lower protein intakes than at higher intakes. As described in "Materials and Methods," five different regression models (first and second order linear regression, logarithmic, oblique, and horizontal regression) were tried to explain the relation between growth and protein intake alone. Of these, the horizontal regression gave the highest $\mathrm{R}_{\text {adj }}$ values both for wt and length growth (Table 3). The interpretation of this model is that it is only up to a certain level that protein is useful for growth. That level, i.e. the cut-point $a$, was $2.77 \mathrm{~g} / \mathrm{kg} /$ $\mathrm{d}$ when studying wt gain and $3.03 \mathrm{~g} / \mathrm{kg} / \mathrm{d}$ when studying length growth (Fig. 1).

Growth versus energy intake. Similar calculations were performed with energy alone instead of protein as explanatory variable (Table 3). Also here, the horizontal regression model seems to be appropriate, giving the highest $\mathrm{R}^{2}{ }_{\text {adj }}$ values with a cut-point of $121.6 \mathrm{kcal} / \mathrm{kg} / \mathrm{d}$ when studying wt gain and 120.2 $\mathrm{kcal} / \mathrm{kg} / \mathrm{d}$ when studying length growth (Fig. 2).

Growth versus natural and added protein. Since the infants

Table 2. Daily nutrient intakes*

\begin{tabular}{|c|c|c|c|c|}
\hline & $\begin{array}{c}\mathrm{HM} \\
(n=7)\end{array}$ & $\begin{array}{l}\text { HMF } \\
(n=7)\end{array}$ & $\begin{array}{c}\text { HMP } \\
(n=7)\end{array}$ & $\begin{array}{l}\text { HMFP } \\
(n=7)\end{array}$ \\
\hline Energy (kcal/kg) & $109.9 \pm 10.0$ & $116.5 \pm 9.0$ & $120.7 \pm 9.9$ & $132.8 \pm 14.0$ \\
\hline Protein $(\mathrm{g} / \mathrm{kg})$ & $2.1 \pm 0.3$ & $2.1 \pm 0.3$ & $3.6 \pm 0.2$ & $3.6 \pm 0.3$ \\
\hline Fat $(\mathrm{g} / \mathrm{kg})$ & $5.7 \pm 0.9$ & $6.7 \pm 0.8$ & $6.3 \pm 1.2$ & $7.8 \pm 1.6$ \\
\hline $\begin{array}{l}\text { Carbohydrate }(\mathrm{g} / \\
\mathrm{kg} \text { ) }\end{array}$ & $12.1 \pm 1.4$ & $11.6 \pm 0.4$ & $11.8 \pm 1.2$ & $11.8 \pm 1.2$ \\
\hline $\begin{array}{l}\text { Sodium (mmol/ } \\
\mathrm{kg}) \dagger\end{array}$ & $1.9 \pm 0.3$ & $1.9 \pm 0.2$ & $2.0 \pm 0.3$ & $2.0 \pm 0.2$ \\
\hline $\begin{array}{l}\text { Potassium } \\
\qquad(\mathrm{mmol} / \mathrm{kg})\end{array}$ & $2.5 \pm 0.2$ & $2.4 \pm 0.2$ & $2.2 \pm 0.1$ & $2.5 \pm 0.2$ \\
\hline $\begin{array}{l}\text { Calcium (mmol/ } \\
\mathrm{kg}) \dagger\end{array}$ & $1.7 \pm 0.2$ & $1.8 \pm 0.2$ & $2.4 \pm 0.3$ & $2.3 \pm 0.3$ \\
\hline
\end{tabular}

with the highest protein intake were those who had been given extra (added) protein, an explanation competing with the one given above is that ultrafiltered HM protein is less useful for growing than the nonsupplemented "natural" protein (or perhaps not even useful at all). This can be formalized as:

$$
\begin{gathered}
\text { growth }=\text { beta }_{0}+\text { beta }_{1} \times \text { natural protein }+ \text { beta }_{2} \times \text { added } \\
\text { protein. }
\end{gathered}
$$

When fitting these models, the following values of $\mathrm{R}^{2}$ adj were obtained (first order linear regression): total protein: 61.3\% (wt), $72.1 \%$ (length) (Table 3); only natural protein: $0.0 \%$ (both wt and length); and, finally, natural and added protein: $61.4 \%$ (wt), $71.1 \%$ (length). This clearly shows that the separation of protein into natural protein and added protein gave no better explanation than what did all protein taken together.

Growth versus protein and energy intake. So far, growth has been described by means of protein intake alone and by energy intake alone. To describe growth simultaneously by means of protein and energy intake, ordinary multiple linear regression was performed. As seen in Table 3 , the values of $\mathrm{R}^{2}$ adj in ordinary linear regression for wt versus protein separately was $61.3 \%$ and for length versus protein separately $72.1 \%$. The $\mathrm{R}^{2}$ adj values for wt versus protein and energy was $63.7 \%$ and for length $71.5 \%$. Thus, introduction of energy adds very little, if anything, to the explanatory power of protein intake alone.

As both protein and energy intake were better at explaining growth through horizontal regression than by ordinary linear regression, we also performed multiple linear regression of growth on min(protein, $a$ ) and energy, as well as on protein and min(energy, $a$ ) (Table 4); in all cases the value of $a$ chosen was that which was optimal in the horizontal regressions earlier reported. These results indicated that protein intake has a larger influence in addition to constant energy than has energy intake in addition to constant protein intake.

As the carbohydrate intake in the four study groups was almost the same (Table 2), differences in energy intake depend mainly on differences in fat intake. Therefore, our results can also be expressed as: fat enrichment in our study has little or no influence on growth rate; improved growth gain is explained by protein intake alone and not by fat intake. This conclusion is also supported by a simple multiple regression analysis; it is only the protein that has a significant non-0 regression coefficient. Furthermore, this conclusion is strengthened by the results for each feeding group presented in Table 5 .

Growth versus protein and nonprotein energy. In an attempt to find a level of nonprotein energy intake below which protein is partly used as an energy source and not entirely for growth, we

Table 4. Growth vs. protein and/or energy, horizontal

\begin{tabular}{|c|c|c|c|c|}
\hline $\mathrm{R}_{\text {adj }}^{2}$ & $\begin{array}{l}\text { Horizontal } \\
\text { protein }\end{array}$ & $\begin{array}{c}\text { Horizontal } \\
\text { protein } \\
\text { and } \\
\text { energy }\end{array}$ & $\begin{array}{c}\text { Horizontal } \\
\text { energy }\end{array}$ & $\begin{array}{c}\text { Horizonta } \\
\text { energy } \\
\text { and } \\
\text { protein }\end{array}$ \\
\hline Wt & $66.1 \%$ & $67.9 \%$ & $43.5 \%$ & $64.3 \%$ \\
\hline Length & $73.4 \%$ & $73.3 \%$ & $41.5 \%$ & $72.8 \%$ \\
\hline
\end{tabular}
regressions

\begin{tabular}{|c|c|c|c|c|c|c|}
\hline & \multicolumn{3}{|c|}{ Protein } & \multicolumn{3}{|c|}{ Energy } \\
\hline & \multirow[b]{2}{*}{$r$} & \multicolumn{2}{|c|}{$\mathrm{R}_{\mathrm{adj}}^{2}$} & \multirow[b]{2}{*}{$r$} & \multicolumn{2}{|c|}{$R_{a d j}^{2}$} \\
\hline & & $\begin{array}{l}\text { linear 1st order } \\
(p=2)\end{array}$ & $\begin{array}{l}\text { horizontal } \\
(p=3)\end{array}$ & & $\begin{array}{c}\text { linear } 1 \text { st order } \\
(p=2)\end{array}$ & $\begin{array}{l}\text { horizontal } \\
(\mathrm{p}=3)\end{array}$ \\
\hline $\mathrm{Wt}$ & 0.79 & $61.3 \%$ & $66.1 \%$ & 0.66 & $41.0 \%$ & $43.5 \%$ \\
\hline Length & 0.86 & $72.1 \%$ & $73.4 \%$ & 0.50 & $22.0 \%$ & $41.5 \%$ \\
\hline Head circumference & 0.41 & $13.7 \%$ & & 0.24 & $2.3 \%$ & \\
\hline
\end{tabular}

Table 3. Growth vs. protein and vs. energy intake 
Table 5. Rate of growth during the study period*

\begin{tabular}{lcccc}
\hline & $\begin{array}{c}\text { HM } \\
(n=7)\end{array}$ & $\begin{array}{c}\text { HMF } \\
(n=7)\end{array}$ & $\begin{array}{c}\text { HMP } \\
(n=7)\end{array}$ & $\begin{array}{c}\text { HMFP } \\
(n=7)\end{array}$ \\
\hline Weight $(\mathrm{g} / \mathrm{kg} / \mathrm{d})$ & $15.3 \pm 3.2$ & $15.9 \pm 2.4$ & $20.0 \pm 1.2$ & $20.4 \pm 2.8$ \\
Length $(\mathrm{cm} / \mathrm{wk})$ & $0.83 \pm 0.17$ & $0.93 \pm 0.17$ & $1.28 \pm 0.12$ & $1.20 \pm 0.17$ \\
Head circumfer- & $0.94 \pm 0.25$ & $1.09 \pm 0.16$ & $1.19 \pm 0.15$ & $1.11 \pm 0.13$ \\
ence $(\mathrm{cm} / \mathrm{wk})$ & & & & \\
\hline
\end{tabular}

* Values represent mean $\pm \mathrm{SD}$.

Weight gain $\mathrm{g} / \mathrm{kg} / \mathrm{day}$

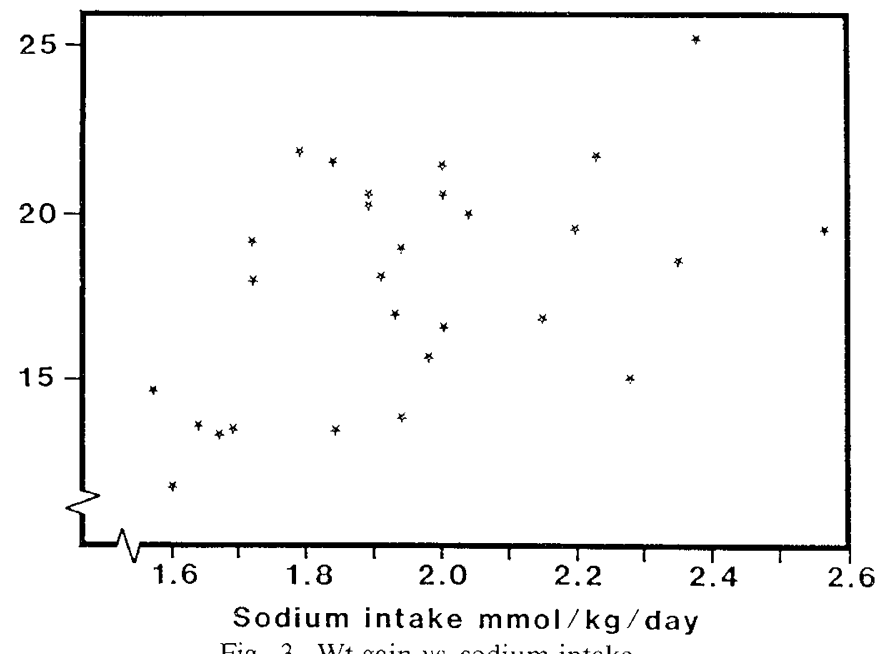

Fig. 3. Wt gain $v$ s. sodium intake.

formulated the hypothesis: If nonprotein energy (np energy) exceeds a certain level $b$, then all protein is available for growth; if nonprotein energy is less than $b$, only the amount [protein $(b-\mathrm{np}$ energy)/4.4] of protein is available for growth (1 $\mathrm{g}$ protein corresponds to $4.4 \mathrm{kcal}$ ). We then tried ordinary horizontal regressions of growth on protein available for growth with varying $b$ to maximize the $\mathrm{R}_{\text {adj }}^{2}(\mathrm{p}=4)$. The results obtained did not support the hypothesis: both for wt and length, the critical level of nonprotein energy intake that produced the best-fitting model was the lowest observed value $(100 \mathrm{kcal} / \mathrm{kg} / \mathrm{d})$. Thus, even at a relatively low total energy intake, we could not find a level where protein was not entirely utilized for growth.

Mother's own milk versus banked milk. By multiple linear regression, we evaluated the effects of mother's own milk versus banked milk on growth. We found no difference in growth if the infants were fed mainly mother's own or banked milk. The main variable related to growth was protein, not its source.

Growth versus sodium and calcium intake. To study the influence of sodium on growth, we performed regressions of wt gain and length growth versus horizontal protein and energy and sodium intake. In all cases, the cut-point for the horizontal variable was chosen to be the same as when sodium was not present. In none of the eight cases was the coefficient of sodium statistically significant. This means that we found no influence of sodium on growth even when the intake was quite low (Fig. 3 ). The same results were obtained when testing possible effects of calcium intake on growth.

\section{DISCUSSION}

When designing this study, we planned four different feeding groups according to protein and fat intakes. However, we found large fluctuations in nutrient intakes mainly due to use of mother's own milk (preferred) with its variation in protein content and also, to some extent, a large variation in fat content in the banked mature milk. By taking daily aliquots of the prepared milk, we were able to determine the actual nutrient intake during the study period. This has allowed us to present nutrient intake data versus growth data as continuous figures and not simply as group data. We conclude that when feeding healthy, AGA and growing VLBW infants with human milk protein, there is no growth advantage supplying more than about $3 \mathrm{~g} / \mathrm{kg} / \mathrm{d}$ and 120 $\mathrm{kcal} / \mathrm{kg} / \mathrm{d}$ of protein and energy, respectively. These intakes permit wt gain equivalent to or better than the calculated intrauterine rate $(29 \mathrm{~g} / \mathrm{d}$ over the corresponding gestational age of 32 to $36 \mathrm{wk}$ ) (21). With regard to energy, these figures are in good agreement with current recommendations $(1,2)$, whereas the value obtained for protein intake is in the lower range of the recommendations.

Other studies regarding growth at varying protein and energy intakes have come to almost the same conclusions, at least concerning energy intake. Moro et al. (22) studied preterm infants fed two identical formulas varying only in energy content (intake 121 versus $141 \mathrm{kcal} / \mathrm{kg} / \mathrm{d}$; protein intake $4.6 \mathrm{~g} / \mathrm{kg} / \mathrm{d}$ ). The result of this study indicated that increasing the caloric intake above $120 \mathrm{kcal} / \mathrm{kg} / \mathrm{d}$ in moderately preterm infants on a relatively high protein intake did not increase linear growth but produced increased wt gain, probably due to increased fat accretion. Kashyap et al. (23) fed low birth wt infants (birth wt 900$1750 \mathrm{~g}$ ) three different formulas providing protein and energy intakes of 2.24 and $115,3.6$ and 115 , and $3.5 \mathrm{~g} / \mathrm{kg} / \mathrm{d}$ and 149 $\mathrm{kcal} / \mathrm{kg} / \mathrm{d}$, respectively. Growth was less in the low-protein group, whereas there was no significant difference between the two highprotein groups.

In the present study, we found little or no influence on growth by fat supplementation. Several reasons for this can be presented. There is a certain risk for losing fat during the passage of the feed through the feeding tube. However, we tried to eliminate this by rinsing the tube with sterile water after each meal. Furthermore, the amount of fat absorbed was not measured. However, as we fed only unpasteurized human milk, most lipase activity should be preserved, and a high rate of fat absorption could be expected $(24,25)$.

We also tried to find a low level of energy intake where protein may partly have been utilized for energy and not entirely for growth, but no such level could be identified by statistical analysis. This is probably due to the fact that no infant had an energy intake of less than $100 \mathrm{kcal} / \mathrm{kg} / \mathrm{d}$. The possibility of characterizing such a cut-off level would probably increase with lower energy intakes than those observed in our study. This is supported by the studies of Putet et al. (26), who reported growth equivalent to the intrauterine rate in VLBW infants fed only proteinsupplemented pooled pasteurized human milk with a daily absorbed energy of only $95 \mathrm{kcal} / \mathrm{kg}$. Moreover, in another study by the same group, they concluded that protein, rather than energy should be added to pooled human milk if a higher growth rate is desirable (27).

The growth rate obtained by our infants is high compared to results from other studies on infants fed protein-rich formula (28). This may partly be explained by the fact that our infants were fed only human milk proteins. They also belonged to a selected healthy group of VLBW infants who started growing after a short period of time (birth wt had been regained after a mean time of only $13 \mathrm{~d}$ ). Finally, the remarkably high growth rate of our infants may partly be attributed to the early initiation of enteral feeding, which may induce early synthesis of intestinal growth-related regulatory peptides (29).

According to several studies, sodium intake may be limiting for growth. A daily intake of at least $3 \mathrm{mmol} / \mathrm{kg} / \mathrm{d}$ is suggested by most investigators (30-32). However, these studies were performed on formula-fed infants. Our infants were fed a lowsodium diet, even including the supplementation with sodium phosphate. In spite of the low intake, we found no correlation between growth data and sodium intake. Some infants with a sodium intake less than $2 \mathrm{mmol} / \mathrm{kg} / \mathrm{d}$ grew more than $40 \mathrm{~g} / \mathrm{d}$. During the study period, only one infant had a serum sodium 
value of $128 \mathrm{mmol} / \mathrm{L}$; all the other samples were above 130 $\mathrm{mmol} / \mathrm{L}$ (overall mean $138 \mathrm{mmol} / \mathrm{L}, n=27$ ).

Our data are not necessarily referable to a sick population of VLBW infants or to infants who have recovered from severe conditions. Nevertheless, to our knowledge, this is the first study presented giving precise data on increasing protein and energy intakes to achieve intrauterine growth in VLBW infants using only human milk proteins.

In conclusion, in healthy growing VLBW, AGA infants fed human milk, the protein and energy intakes required to achieve optimal growth are about $3 \mathrm{~g} / \mathrm{kg} / \mathrm{d}$ and $120 \mathrm{kcal} / \mathrm{kg} / \mathrm{d}$, respectively. Increased fat intake did not influence growth rate in our study; neither did sodium nor calcium intake. The variable affecting growth was protein alone, and protein may be the only macronutrient needed for fortification when feeding the VLBW infant with human milk.

Acknowledgments. The authors acknowledge the valuable help of Professor Harry Smith, M.D., Department of Biostatistics, Mount Sinai School of Medicine, New York, in designing this study. We also thank Nestle Nutrition and the Nordreco Company, Bjuv, for the human milk protein and fat preparations. We are also grateful to Professor Arne Dahlquist (deceased), Assistant Professor Margareta Jägerstad, and Technician Ulla Lindquist, Department of Nutrition, Chemical Center, University of Lund, for performing the milk nutritional analyses.

\section{REFERENCES}

1. Committee on Nutrition of the American Academy of Pediatrics 1985 Nutritional needs of low-birth-weight infants. Pediatrics 75:976-986

2. Committee on Nutrition of the Preterm Infant, European Society of Paediatric Gastroenterology and Nutrition (ESPGAN) 1987 Acta Paediatr Scand (suppl) 336:2-14

3. Räihä NCR, Heinonen K, Rassin DK, Gaull GE 1976 Milk protein quantity and quality in low-birth-weight infants: I. metabolic responses and effects on growth. Pediatrics 57:659-674

4. Svenningsen NW, Lindroth M, Lindquist B 1982 Growth in relation to protein intake of low birth weight infants. Early Hum Dev 6:47-58

5. Järvenpää A-L, Räihä NCR, Rassin DK, Gaull GE 1983 Preterm infants fed human milk attain intrauterine weight gain. Acta Paediatr Scand 72:239243

6. Davies DP 1977 Adequacy of expressed breast milk for early growth of preterm infants. Arch Dis Child 52:296-301

7. Schanler RJ, Oh W 1985 Nitrogen and mineral balance in preterm infants fed human milks or formula. J Pediatr Gastroenterol Nutr 4:214-219

8. Atkinson SA, Bryan MH, Anderson GH 1987 Human milk: difference in nitrogen concentration in milk from mothers of term and premature infants. J Pediatr 93:67-69

9. Lemons JA, Moye L, Hall D, Simmons M 1982 Differences in the composition of preterm and term human milk during early lactation. Pediatr Res 16:113117

10. Atkinson SA, Bryan MH, Anderson GH 1981 Human milk feeding in pre- mature infants: protein, fat, and carbohydrate balances in the first two weeks of life. J Pediatr 99:617-624

11. Chessex P, Reichman B, Verellen G, Putet G, Smith JM, Heim T, Swyer PR 1983 Quality of growth in premature infants fed their own mother's milk. J Pediatr 102:107-112

12. Gross SJ 1983 Growth and biochemical response of pretcrm infants fed human milk or modified infant formula. N Eng! J Med 308:237-241

13. Schanler RJ, Garza C, Nichols BL 1985 Fortified mother's milk for very low birth weight infants: results of growth and nutrient balance studies. $\mathbf{J}$ Pediatr 107:437-445

14. Reichman B, Chessex P, Putet G, Verellen B, Smith JM, Heim T, Swyer PR 1981 Diet, fat accretion, and growth in premature infants. N Engl J Med 305:1495-1500

15. Lucas A, Gore SM, Cole TJ, Bamford MF, Dossetor JFB, Barr I, DiCarlo L, Cork S, Lucas PJ 1984 Multicentre trial on feeding low birthweight infants: effects of diet on early growth. Arch Dis Child 59:722-730

16. Lucas A, Lucas PJ, Chavin SI, Lyster RLJ, Baum JD 1980 A human milk formula. Early Hum Dev 4:15-21

17. Rönnholm KAR, Perheentupa J, Siimes MA 1986 Supplementation with human milk protein improves growth in small premature infants fed human milk. Pediatrics 77:649-653

18. Hylmö P, Polberger S, Axelsson I, Jakobsson I, Räihä N 1984 Preparation of fat and protein from banked human milk: its use in feeding very-low-birthweight infants. In: Williams AF, Baum JD (eds) Human Milk Banking, Raven Press, New York, pp 55-61

19. Scott TA, Melvin EH 1953 Determination of dextran with anthrone. Anal Chem 25:1656-61

20. Merrill AL, Watt BK 1955 Energy value of foods, basis and derivation. US DAgriculture, Agricultural Handbook No 74

21. Persson P-H, Weldner B-M 1986 Intrauterine weight curves obtained by ultrasound. Acta Obstet Gynecol Scand 65:169-173

22. Moro G, Minoli I, Heininger J, Cohen M, Gaull G, Räihä N 1984 Relationship between protein and energy in the feeding of preterm infants during the first month of life. Acta Paediatr Scand 73:49-54

23. Kashyap S, Forsyth M, Zucker C, Remakrishnan R, Dell RB, Heird WC 1986 Effects of varying protein and energy intakes on growth and metabolic response in low birth weight infants. J Pediatr 108:955-963

24. Järvenpäa A-L 1983 Feeding the low-birth-weight infant: IV fat absorption as a function of diet and duodenal bile acids. Pediatrics 72:684-689

25. Hernell O, Blackberg L, Olivecrona T 1981 Human milk lipases. In: Lebenthal E (ed) Textbook of Gastroenterology and Nutrition in Infancy. Raven Press, New York, pp 347-354

26. Putet G, Rigo J, Salle B, Senterre J 1987 Supplementation of pooled human milk with casein hydrolysate: energy and nitrogen balance and weight gain composition in very low birth weight infants. Pediatr Res 21:458-461

27. Putet G, Senterre J, Rigo J, Salle B 1984 Nutrient balance, energy utilization, and composition of weight gain in very-low-birth-weight infants fed pooled human milk or a preterm formula. J Pediatr 105:79-85

28. Ziegler EE 1986 Protein requirements of preterm infants. In: Fomon SJ, Heird WC (eds) Energy and protein needs during infancy. Academic Press, Orlando, Florida, pp 69-85

29. Lucas A, Bloom R, Aynsley-Green A 1986 Gut hormones and "minimal enteral feeding." Acta Paediatr Scand 75:719-723

30. Roy RN, Chance GW, Radde IC, Hill DE, Willis DM, Sheepers J 1976 Late hyponatremia in very low birthweight infants $(<1.3$ kilograms). Pediatr Res 10:526-531

31. Chance GW, Radde IC, Willis DM, Roy RN, Park E, Ackerman I 1977 Postnatal growth of infants of $<1.3 \mathrm{~kg}$ birth weight: Effects of metabolic acidosis, of caloric intake, and of calcium, sodium, and phosphate supplementation. J Pediatr 91:787-793

32. Al-Dahhan J, Haycock GB, Nichoil B, Chantler C, Stimmler L 1984 Sodium homeostasis in term and preterm neonates. Arch Dis Child 59:945-50 